\title{
Negligence, Strict Liability and Regulation of Safety under Belgian law: An Introductory Economic Analysis
}

\author{
by Michael Faure* and Roger Van den Bergh**
}

\section{Introduction}

1. In this paper Belgian law, a civil law based legal system, will be presented as a test of a number of hypotheses, developed in the economic analysis of tort law. For this purpose we will use the economic model of tort law, developed by American scholars (Brown, 1973, Diamond, 1974, Landes and Posner, 1981 and 1984, Polinsky, 1980 and 1983, Shavell, 1980). This paper relies on prior research, which examined the efficiency of the Common Law. By extending the analysis to Belgian law it however applies the model in a different legal context. It illustrates that the economic model of tort law is also suited for analyzing civil law concepts, such as the bonus pater familias and force majeure. Since these roman law based concepts have influenced many civil law tort systems, the points made in this paper have implications for other countries than Belgium.

The claim of this paper is not that Belgian tort rules are efficient from a deterrence viewpoint. The present accident law is a mix of liability rules, insurance and safety regulation. This makes it very difficult to draw conclusions on efficiency. In addition, actual cases may deviate from the theoretical standards that are involved. For instance, the discretion of the judge implies that he is free to apply the fault standard without taking into account economic criteria.

For readers unfamiliar with the basic economic model of tort law, we will briefly summarize it. Afterwards we will proceed with the Belgian cases. First we will test whether concepts of Belgian tort law correspond with economic liability concepts, such as the famous Learned Hand rule. Second we will confront the cases of strict liability under Belgian law with the currently advanced economic reasons for strict liability. In the economic analysis of law tort law is seen as an instrument to deter activities, worth to be avoided on efficiency grounds through liability rules. The expectation to be held liable ex post should

\footnotetext{
${ }^{*}$ LL.M. University of Chicago, Attorney at the Antwerp Bar.

** Doctor in Law, Professor at the Antwerp Business School, Assistant Professor at the University of Antwerp Law School.

The authors wish to thank Jan C. Bongaerts, Bruno Peeters, Göran Skogh, Aloïs Van Oevelen and two anonymous referees for useful comments. They however are solely responsible for the content of the paper.
} 
induce parties ex ante to take care or change the activity level in view of reducing the accident risf. Safety regulation combined with criminal sanctions can be seen as an alternative device. Several criteria can be found in the literature with respect to the combination of tort liability and safety regulation (Calabresi, 1970, Wittman, 1977, Skogh, 1982, Shavell, 1984). We will test these criteria to the Belgian case and look for an "optimal mix" of these devices.

Since the Belgian legal system, like many others, does not see safety regulation as a complete alternative for liability rules, the question arises which liability rule (the fault rule or strict liability) should be preferred in combination with safety regulation. This problem has received less attention in the literature. We will address this question in the last part of the paper.

\section{The economic model of tort law}

2. Accident law can be seen as a means to achieve efficiency, that is to minimize the sum of accident costs and the costs of accident avoidance (Calabresi, 1970, Calabresi and Hirschoff, 1972, 1057). This sum, called the social costs of accidents, can be presented as follows:

$\mathrm{C}=\mathrm{p}(x, y) L+\mathrm{A}(x)+B(y)$, where:

$\mathrm{C}=$ the sum of expected accident costs and the costs of care,

$\mathrm{A}=$ the victim,

$B=$ the injurer,

$\mathrm{x}=$ level of care of the victim,

$y=$ level of care of the injurer,

$\mathrm{p}=$ probability that an accident will occur,

$\mathrm{L}=$ magnitude of the loss.

It is assumed that both parties are risk neutral, that the magnitude of the loss $(\mathrm{L})$ is independent of the level of care, that more care will reduce the probability (p) of an accident and that only the victim (A) suffers a loss. To minimize the social costs (C) the levels of care must be set at $x=x^{*}$ for the victim and $y=y^{*}$ for the injurer. At these efficient levels, the marginal benefits from an increase in care (reduction of $\mathrm{p}(x, y) L$ ) equal the marginal costs of greater care (Brown, 1973, 326). Since in a tort situation transaction costs are mostly prohibitive (Veljanovski, 1981,131), the efficient levels $x^{*}$ and $y^{*}$ will not be reached through voluntary negotiations. Therefore the legal system should intervene to provide rules which will lead to the efficient levels of care ${ }^{1}$.

3. We will first consider which liability rule will lead to these efficient levels of care, assuming that only the attitude of the injurer influences the accident risk. Belgian tort law, as most legal systems, distinguishes between liability based on a fault rule and liability without fault, called strict liability. Under a strict liability rule A will always receive compensation, irrespective of the conduct of B. To minimize his costs, B will take care up to the optimal point $y^{*}$. Since under these conditions the injurer's costs equal the social costs (C), efficiency will be reached by spending $y^{*}$ on care. This rule will provide a complete internalization of the externality created through the accident situation.

1 Voluntary negotiations might be possible in a product liability setting (see Veljanovski, 1981, 139). In that case legislative intervention could contain information remedies. This might provide the framework for a Coasian solution. 
Under a negligence rule the injurer will only have to bear the loss if he uses less than a legally required level of care, called due care. This will be abbreviated as $y^{l}$ (the level of care required by the legal system). Assuming that $y^{l}=y^{*}$, the injurer will spend $y^{*}$ on care, which in this case is the cheapest solution for him ${ }^{2}$. Under a negligence rule an efficient outcome will therefore be reached as long as the legal system defines $y^{*}$ as due care.

Both a strict liability rule and a negligence rule will therefore lead to the optimum in cases where the victim's care does not influence the probability of an accident. Most accident situations are "joint care" cases. In this situation $\mathrm{p}(x, y) L$ is also influenced by the behaviour of the victim. A simple strict liability rule would not lead to the efficient result, since the victim has no incentive to spend on care. To remedy this problem, the victim might be considered "contributorily negligent" if he does not take due care. A contributory negligence rule, as known in the Common Law, excludes a right to compensation for the victim who did not take due care.

Assuming that $x^{l}=x^{*}$, whereby $x^{*}$ is the legally required level of care for the victim, the victim will have the incentive to take optimal care. If he would not take due care he would be found negligent as well and would receive no compensation. An efficient result will also follow both under a simple negligence rule and under a negligence rule with a contributory negligence defense. In both cases the injurer will spend $y^{*}$ on care and the victim will, in order to avoid to bear the loss himself, spend $x^{*}$ on care.

4. In the joint care case strict liability with contributory negligence and a negligence rule (with or without contributory negligence) will incite parties to adopt efficient levels of care. However, the accident risk cannot totally be minimized by increasing the levels of care. Accident losses depend also on the extent to which parties participate in the activity which might cause the damage (for instance the miles driven). Therefore, reducing the activity level will also reduce the accident risk (Diamond, 1974, Polinsky, 1983, 44, Shavell, 1980). The activity level can be interpreted as any control variable not taken into account in setting $y^{l}$. Under a negligence rule an injurer has no incentive to adopt an optimal level of activity. He will be released from liability if he takes due care, irrespective of his activity level. This cannot be remedied, because judges cannot easily calculate the optimal activity level into the due care standard ${ }^{3}$. A strict liability rule has the advantage that the injurer will automatically adopt an optimal activity level. This is also a means to minimize his costs. If the victim's activity has no influence on the accident risk, strict liability might have a slight advantage, because it might also lead to an optimal activity level of the injurer. However, in a joint care case this advantage is cancelled out by the fact that the victim will not adopt an optimal activity level. This is due to the impossibility of calculating the activity level into the due care standard, when considering contributory negligence (Diamond, 1974, Landes and Posner, 1981, Polinsky, 1983, Shavell, 1980).

5. Since activity level changes are not calculated into the due care standard, strict liability (with a defense of contributory negligence) will encourage activity level changes of the injurer. On the other hand, a negligence rule will encourage activity level changes of the

${ }^{2} \mathrm{~B}$ will exercise due care since $\mathrm{p}\left(o, y^{o}\right) L+\mathrm{B}\left(y^{o}\right)$ is always higher than $\mathrm{B}\left(y^{*}\right)$. If the injurer spends $y^{*}$ on care he will not have to pay damages (Landes and Posner, 1981).

${ }^{3}$ It is difficult to determine both the optimal and the actual activity level (for examples, see Polinsky, 1983, 47 and Shavell, 1980, 2). 
victim. Therefore, several authors suggest that strict liability will be a superior device if it is more important to give injurers an incentive to change the activity level than that victims be given a similar incentive (Landes and Posner, 1981, 877, Shavell, 1980, 7 and 19). This implies that if the injurer's activity is very dangerous and creates a high accident risk, even if $y^{*}$ is spent on care, it will be more desirable to control the injurer's activity than it is to control the victim's. For instance, if an injurer creates the collapse of an old house with explosives in the middle of a densely populated area, it is more desirable to control his activity than it is to control the victim's. On the other hand, the advantage of a strict liability rule disappears if the injurer's activity is not important enough to be controlled. For instan$\mathrm{ce}$, if the injurer runs to catch a train and collides with another pedestrian, a negligence rule would be superior, because it is at least as important to control the victim's activity than it is to control the injurer's. If the activity of the injurer is not very dangerous, if exercised with reasonable care, it is desirable to give the victim an incentive to take an optimal activity level as well.

Even though a clear cut test is therefore difficult to give, Landes and Posner describe several factors which may lead to a preference for a strict liability rule (Landes and Posner, $1981,907)$. These elements are: 1 . high expected accident costs; 2 . the impossibility that more care by the injurer would reduce the accident risk; 3 . the impracticability of constraining the victim's activity in favour of the injurer's and 4 . the desirability to reduce the risk by an activity level change of the injurer.

6. Notwithstanding the fact that both a fault rule and strict liability create efficient incentives to take care, there are distributional differences. As will be developed further, the implementation of strict liability under Belgian law is to a large extent influenced by these considerations. In addition, there might also be differences in the costs of administering the rules (Brown, 1973, 343, Chelius, 1976, 294, Landes and Posner, 1981, 873).

\section{Economic analysis of Belgian fault liability}

7. We will now examine the efficiency implications of the Belgian fault system, relying on the economic model of tort law just described. To reach efficiency the injurer has to be found negligent if he exercided less than due care $\left(y<y^{*}\right)$. Asuming that $y^{*}$ is defined correctly, this should lead to the appropriate incentives to take care. In American case law the application of the famous Learned Hand Standard ${ }^{4}$ leads to a finding of negligence if the burden of precaution is lower than the probability of an accident which causes the loss (this means that B $(y)<p . L)$. Such appreciation seems to fit into the model, although $y^{*}$ from the model, as has been stressed by Brown (1973, 332-333), is defined in marginal terms.

Under Belgian law the general liability rule relates to the fault concept, laid down in article 1382 of the Code Civil ${ }^{5}$. There are two categories of fault: the violation of a statutory or regulatory norm and the breach of the general duty of care. In legal practice most of the

\footnotetext{
${ }_{4}^{4}$ United States v. Caroll Towing Co., 159 F. 2d 169 (2d Cir. 1947). For a test of American cases to the Learned Hand standard, see Posner, 1972.

5 "Any act by which a person causes damage to another makes the person through whose fault the damage occurred liable to make reparation for such damage".
} 
liability cases come within the first category. Whether a certain conduct violates the general duty of care has to be appreciated by reference to the standard of the so called bonus pater familias, a Roman Law based concept. This standard is still applied in French Law oriented countries like Belgium. It refers to the conduct of a normally careful and prudent person, capable of conducting himself with care and diligence (Limpens, Kruithof and Meinertzhagen-Limpens, s.d., 2-25). In the context of the appreciation of the duty of care the foreseeability of the damage is another condition for liability. The injurer is liable if the harm caused by the act is reasonably foreseeable and if he nevertheless did not take the necessary measures to prevent the accident.

The determination of the fault under Belgian law does not sound like Judge Learned Hand's calculus of negligence. Although the three variables of the Hand Standard are not fully and expressly examined, some considerations in judgements could be interpreted as referring to these variables. With respect to the first variable, the probability that an accident will occur, an indication seems to be the condition of foreseeability of the loss. The foreseeability could be refined to the (probability $x$ loss) from the Hand Standard. Still this is not a clear cut application of the Hand Standard, since it does not equal the mathematical probability that an accident will occur. Neither do judges explicitly examine whether additional care would bring any additional benefit in reduction of expected damages. Therefore, the condition of the foreseeability of the loss does not entirely cover the first variable of the Learned Hand Standard, neither in its literal version, nor in its incremental version.

Another variable of the Hand Standard, the burden of precaution adequate to prevent accidents, is absent in the determination of a fault consisting in a violation of a statutory or regulatory norm commanding or prohibiting a specific condıct. Considering the burden of precaution under the general duty of care, judges will refer to the standard of the bonus pater familias. We will now test this concept to the inodel.

8. The costs of care and therefore $y^{*}$ (the efficient care) might be different for every individual. If the legal system could, at relative low costs, distinguish between the several types of injurers, it would be efficient to hold them to different standards of care (Diamond, 1974, 123, Pesner, 1977, 125). Of course, the costs involved with administering such a system of detailed classification will often be too high. Therefore, we would expect that if classification of the due care standard is too costly, the legal system would set the standard at a certain average level of $y^{*}$.

Under Belgian law the appreciation of the care exercised by the bonus pater familias is done "in the abstract". An appreciation "in the concrete", which would take circumstances such as age, education or intelligence of the injurer into account, is very costly. However, if classification can be done at relatively low costs, it will also be found in Belgian law. Professional liability offers an example. If e.g. a doctor's conduct is examined, the criterion will not be the conduct of a careful and prudent person, but of a normally careful doctor. The average $y^{*}$ standard will not be the average standard of a citizen, but the average standard of a doctor. This gives the doctor the appropriate incentives to take efficient care. In this case classification is not very costly, since it is clear that a professional can take care at lower costs than a normal citizen, as far as it concerns his professional activity. Belgian case law offers many examples. A judge held a doctor liable in the following case. A victim of a 
traffic accident, who complained of a light headache, was sent home after a superficial examination by the doctor. A few days later the victim died from the consequences of a fracture of the skull, caused by the accident. The failure to employ the means of a normally careful doctor (e.g. a radiographical examination) was considered wrongful ${ }^{6}$.

9. Under Belgian law the fault will only make the injurer liable if the act is imputable to him. This condition of blameworthiness relates to the free will and the capacity of discretion of the tortfeasor (Vandenberghe, 1980, 1170-1171). Therefore, children who did not reach the age of discretion yet, the so called infantes cannot incur any personal liability. There is a clear economic rationale for the requirement of blameworthiness. If the injurer does not act of his free will, liability does not seem to have any influence on the incentives to take care. Liability would only cause the administrative costs of shifting the loss, without any compensating benefit for the incentives.

Whenever liability is still imposed in cases where the victim did not act out of his free will, equity reasons seem to be the underlying rationale. We will briefly examine two applications of the blameworthiness-requirement: force majeure and mental patients.

Belgian case law on traffic accidents offers illustrations of the force majeure - reasoning. If a traffic accident is caused by a heart-attack or an epileptic faint, the injurer will not be liable. The injurer cannot call on the exception of force majeure if he knew or should have known of such a possibility. It has been decided that a patient who suffers from a heartcondition and despite the advice of his doctor not to drive his car anymore, nevertheless does so will be fully liable for the damage caused by an accident due to his unconsciousness $^{7}$. This decision is straightforward. To hold an injurer who unexpectedly suffers a heartattack liable would not influence his level of care or his activity level.

Liability would not affect the incentives of mental patients who are in such a state of mind that they cannot control their acts. Before the Act of 1935 Belgian law generally shared that point of view. In 1935 the rule was changed for equity reasons. The judge can now order the mental patient to pay compensation, depending on his wealth and the existence of insurance coverage. In cases where the civil liability of the mentally ill injurer has been insured, judges usually hold the injurer liable (Vandenberghe, 1980, 1179). In such cases the decision on liability is clearly influenced by the existence of insurance coverage, which is rather exceptional under Belgian law ${ }^{8}$. Although a total or partial shifting of the loss will have no influence on the incentives and is therefore inefficient in the Posnerian view on tort law, the concern for victim compensation seemed more important.

${ }^{6}$ Court of Appeals Brussels, January 19, 1965, Pasicrisie belge, 1966, II, 13.

${ }^{7}$ Police Court Namen, December 24, 1975, Pasicrisie belge, 1976, III, 66.

${ }^{8}$ Outside of the area of mentally ill patients the existence of insurance coverage is not taken into consideration. Exceptional is one decision of the Justice of the Peace of Merksem, where the existence of insurance coverage is expressly taken into account as an argument to divide the loss between the parties involved in a traffic accident (April 9, 1981, Rechtskundig Weekblad, 1981-82, 1279 with a comment by Dries Simoens). 
Attention should be drawn to a refinement of the solution just mentioned. If the mental patient is only lower qualified, but not totally incapable of controlling his acts, he will normally be held liable under Belgian case law. Such person will be held by the legal system to the due care standard of the average normal citizen which he can never meet. Even though he can never come up to the average efficient care standard, such a mental patient could make the trade-off between the benefits of the activity on the one hand and the total costs on the other hand. This might lead to a change in his activity (See Landes and Posner, 1981, 879-880).

10. Discussing the economic model of tort law we indicated that both a strict liability rule in combination with a defense of contributory negligence and a negligence rule (with or without contributory negligence) will give appropriate incentives to the victim to spend $x^{*}$ on care. (Brown, 1973, 340-342; Calabresi, 1975, 663; Landes and Posner, 1981, 880882).

A comparative negligence rule has the effect of proportionally dividing the loss between the injurer and the victim, if both committed a fault. Under this rule the right to compensation will be proportionally reduced if the victim was negligent. The injurer will still take efficient care to avoid liability, while the victim still takes care to minimize his own loss (Haddock and Curran, 1985, 59-63). The efficiency of this rule is debated in the literature. Haddock and Curran point at difficulties in analysing the comparative benefits of comparative negligence versus a contributory negligence defense (Haddock and Curran, 1985). It is well known that Posner is an opponent of this rule (1977), 123-124). According to him the rule causes considerable administrative costs, without any compensating benefits for the incentives to take care. Not only is an intervention of the legal system necessary to shift a part of the loss from the victim to the injurer, but judges will also have to examine the faults of both parties and the proportion in which they contributed to the loss. Posner argues that comparative negligence makes economic sense only when society wants to use the tort system to provide insurance to accident victims (Posner, forthcoming, 253-254).

Under Belgian law the victim's fault is not considered a complete defense on behalf of the injurer, as is often the case in Common Law countries". If the victim's fault can be proven, his right to compensation will be reduced by the degree his fault contributed to the loss. The following case gives an illustration. Boys and girls were chatting together when a boy showed a living spider to a sixteen year old girl. The girl jumped away in a panic reaction and was harmed. The judge reduced her right to compensation by one fifth, because he qualified her reaction as exaggerated ${ }^{10}$. This seems to be comparable to the above described comparative negligence rule.

With respect to Posner's suggestion that a comparative negligence rule is only efficient if tort law were to have an insurance function, it is interesting to note that even in fields where there is compulsory insurance, such as car accidents, comparative negligence is applied.

\footnotetext{
${ }^{9}$ It should be noticed that also in the Common Law there is an important tendency towards comparative negligence. The all-or-nothing approach does not seem to be the general rule anymore (Epstein, Gregory and Kalven, 1984, 488-505).

${ }^{10}$ Civil Court Ghent, January, 7, 1974, Revue générale des assurances et des responsabilités, 1974, 9335.
} 


\section{Economic analysis of strict liability under Belgian law}

11. In cases of strict liability the injurer can be held to pay compensation, even if he did not commit the fault which caused the loss. Even though Belgian law remains mainly based on the fault concept, in legislation and case law several cases of strict liability have been created.

Cases of strict liability were already present in the Code Civil of 1804 . In this respect we could mention the liability of the guardian of a defective property (art. 1384, al. 1, C.C.); the liability of the employer for damage caused by his employee (art. 1384, al 3 C.C.); the liability of the proprietor or the guardian of an animal (art. 1385 C.C.) and the liability of the owner of a building for the damage caused by its collapse (art. 1386 C.C.). Cases of strict liability are also laid down in special statutes. A listing of these cases can be found in the appendix.

Belgian legal scholars generally favour an increasing reliance on strict liability. This support cannot remain undiscussed when we test the arguments advanced in Belgian legal doctrine to the economic model of tort law.

\subsection{Belgian legal doctrine}

12. Many cases of strict liability in the Code Civil are traditionally explained as a presumption of fault. For instance, the strict liability of the owner of a building for its collapse is based on a presumption of fault in the construction or the maintenance of the building (article 1386 C.C.). These presumptions, however, are no longer upheld in modern tort doctrine.

The theory of the "created risk" is advanced as an alternative explanation. This theory holds that a person, who performs a dangerous activity and receives a benefit from this performance, has to bear the loss caused through the creation of the risk (Simoens, 1980-81, 1972-1976). For instance, in cases of nuclear energy accidents strict liability seems to be based on the created risk theory (Bocken, 1984, 394).

A connected reason is that some activities create ultrahazardous risks. Even if the injurer pays the highest possible care, accidents sometimes cannot be avoided. This is considered to be a reason for strict liability in the case of nuclear energy accidents. In addition, the same rationale is given to justify the strict liability rule in the Mining Act, in the Act on the transportation and storage of natural gas, in the Act on groundwater and in the Act on fire or explosion in public buildings.

Difficulties of proof are also mentioned as a reason for imposing strict liability. It may be difficult for the victim to prove fault or causation. For instance, the appreciation of the fault is more difficult if the use of new techniques is involved. On the other hand, causation may be difficult to prove if a long period of time passes before the harm becomes apparent or if several injurers are involved and it is difficult to prove whose conduct caused the harm. These considerations led to strict liability in the cases mentioned above and for accidents on the ground caused by aeroplanes (Bocken, 1984).

Finally "victim protection" is stressed as a main concern of Belgian liability law (Van Oevelen, 1986, Peeters, 1985-1986, 1326). This concern is apparent in article 1384, al. 3, C.C.. The employer is, as a solvent debtor, bound to compensate the innocent victim, who 
eventually would not get compensation from the insolvent employee. Also for other cases, authors stress the importance of equity grounds for the introduction of strict liability (Bocken, 1984, 376-377).

\subsection{Legal versus economic doctrine}

13. When we discussed the economic model of tort law we noted that high accident costs are advanced as an argument in favour of strict liability. Also lawyers stress the magnitude of the loss as a reason for introducing strict liability. This statement, however, needs a refinement. Assuming that the accident costs exceed the injurer's wealth, strict liability might lead to underterrence. Since the injurer is not able to pay the compensation, strict liability might not lead to efficient incentives to take care. If the value of the loss exceeds the injurer's assets, he will not have an incentive to take due care under a strict liability rule: even if he takes due care, he will have to pay for the total damage. He will spend therefore less than $y^{*}$ on care. In this respect Landes and Posner suggest that a fault rule provides better incentives. Under a fault rule the injurer will still spend $y^{*}$ on care as long as his assets are higher than the costs of spending $y^{*}$ on care (Landes and Posner, 1984, 421-422, where mathematical proof of this statement is also provided).

This leads us to a conclusion which will surprise most Belgian lawyers. Although high expected accident costs are generally considered an argument in favour of strict liability, a fault rule might provide better results if the loss is of such a magnitude that it exceeds the injurer's assets. Therefore, the argument of increased losses, considered separately, does not seem sufficient for the introduction of strict liability rules.

14. Referring to the reasons given for strict liability in Belgian legal doctrine, many of those reasons seem to coincide at first sight with the economic reasons for strict liability. Despite differences in the wording, the theory of the "created risk" and the reference to the ultrahazardous character of the activity, remind of some elements of the economic approach. The impossibility that more care by the injurer would reduce the accident risk is almost literally stressed by Belgian legal doctrine as an argument for strict liability. Even though activity level changes are not literally considered in Belgian legal doctrine, these elements seem to be considered implicitely in the notion of "ultrahazardous risk". However, a clear reference to those influences cannot be found in the argumentation.

Difficulties of proof and causal uncertainty are also mentioned as reasons for strict liability in Belgian legal doctrine. It is not clear from the economic model why the introduction of strict liability would be helpful for solving these problems. If the problem were limited to the determination of negligence, strict liability could indeed help. However, to be found liable, the harm must always be attributed to the injurer. If it is impossible to find the injurer, strict liability would not help either.

Many situations of strict liability in Belgium can only be explained on equity grounds. Economists, considering themselves as "formalists", similarly indicate that the formal approach aims for a particular kind of insight, but not for true balance, so that the implementation of strict liability cannot only be explained on economic reasons (Shavell, 1980, 24, Calabresi and Hirschoff, 1972, 1084). It is important to note, however, that in Posner's view compensation to the victim is only instrumental to attaining efficiency, but not always 
required (Polinsky, 1974, 1665). In that respect other scholars argue that strict liability is always a preferred rule, because it would suffice the needs of a corrective justice system (Epstein, 1973, Veljanovski, 1981, 139).

15. Some legal scholars point at increasing industrialization as an explanation for the evolution towards strict liability. Industrialization increases the magnitude of the losses and the complexity of the accidents. Simoens argues that liability based on a fault concept was in fact meant for an agricultural society and is no longer adapted for an industrialized society (Simoens, 1980-81, 1970-1972) ${ }^{11}$.

Landes and Posner argue that in an early stage of the development of a new activity sufficient knowledge to determine whether the benefits of that activity to society exceed the full social costs is lacking (Landes and Posner, 1981, 910-913). In such a situation strict liability has the advantage that the injurer will have to internalize all the costs of his activity. For an injurer in a strict liability situation, his total costs equal the social costs, assuming that $x^{*}$ $=0$ (Polinsky, 1980, 364, Polinski, 1983, 39, Shavell, 1980, 11). The injurer will therefore not only take efficient care, but adopt an efficient activity level as well. If the injurer stays in the activity, in spite of the strict liability standard, Landes and Posner argue that the benefits of the activity will certainly exceed the full social costs. When the activity has proven to be beneficial, strict liability is no longer required, since it will only lead to an increasing amount of litigation and high legal costs, without any compensating benefit. Their suggestion is that if the injurer "survives" the strict liability standard, he has proven to be efficient. Hence, the strict liability standard can be replaced by a negligence rule to save on costs. The argument is supported by the case of liability for aeroplane accidents in American law (Landes and Posner, 1981, 910).

This analysis will again be surprising to most Belgian lawyers. In fact, as the survey of strict liability cases in Belgium indicates, liability for accidents resulting from a new activity was always governed by the fault standard. After the deficiencies of the standard became visible, the legislator introduced strict liability to overcome these problems. In fact, industrialization is the framework into which the above mentioned reasons for strict liability in Belgium fit. Increasing technicity increases the number of ultrahazardous activities, which are hard to avoid. Moreover, industrialization leads to accidents for which fault and a causal relationship between fault and harm are often difficult to prove. These arguments in favour of strict liability thus become more convincing as industrialization increases.

16. The tendency, described by Landes and Posner, from strict liability towards negligence raises some further problems. Their argument, based on the saving of legal costs in favour of the negligence rule, does not seem convincing. The application of a negligence rule also involves considerable costs (see Chelius, 1976, 294). Second, there is no guarantee that the activity will remain efficient after the introduction of a negligence standard. Landes and Posner seem to presume that no further changes occur after the introduction of the

11 Although this argument is often advanced as an explanation, we are not convinced that a fault rule was typical for an agricultural society. During the discussions preceeding the draft of the Code Civil an increasing application of the fault principle was stressed. In a non industial society (which was largely the case in Europe before 1804) strict liability was the general rule. Insurance markets were non-existent and criminal law relatively undeveloped (Veljanovski, 1981, 140-141). 
negligence standard. However, changes in the benefits of the activity to the injurer, as well as changes in the social costs of the activity can occur. Therefore, the shift to a negligence standard will only be efficient if a constant monitoring and controlling of the injurer's activity could be performed at low costs.

Finally, an alternative explanation for the example of aeroplane accidents, which is given in support of the theory of Landes and Posner, can be advanced. The application of a fault standard implies the knowledge of the efficient level of care $\left(y^{*}\right)$. In an early stage of industrialization, information to set this standard properly may be lacking. The introduction of a strict liability standard at that stage might precisely be explained by that imperfection. This seems to correspond to the difficulties of proof, stressed by Belgian legal doctrine as an argument for the introduction of strict liability. Since information to apply the due care standard properly is not available, strict liability has the advantage that the injurer will make a correct decision on whether to stay in the activity or not (compare Calabresi, 1975, 667-670). When the dangers and the benefits of the activity become more known, a change to a negligence rule might be plausible.

17. The economic reasons for strict liability described above can be used to explain most Belgian strict liability cases laid down in special statutes. In cases of, for instance, fire or explosion in public buildings, accidents with nuclear reactors and damage on the ground caused by aeroplanes, it seems better to control the injurer's activity than the victim's. In those cases the high risk of the activity seems evident and controlling the victim's activity of minor use. How could a person who is hit by an object falling out of an aeroplane take appropriate measures to avoid the accident risk?

Although the Belgian case provides substantial support for the economic test of strict liability, it would be erroneous to think that the present legal situation can be totally explained by such an analysis. It is easier to fit all the existing Belgian cases of strict liability into the model, than it is to explain why for several ultrahazardous activities (e.g. accidents caused by the chemical industry) strict liability is not imposed yet.

The latter can partly be attributed to the characteristics of the Belgian legislative process. Some strict liability statutes were clearly introduced ad hoc. Legislative action often was the consequence of a certain incident. Several spectacular fires in public buildings demonstrated the need for legislative action ${ }^{12}$. The Act on toxic waste came as a direct reaction to the discovery of several depositories where cyanide had been found ${ }^{13}$. Most striking was the implementation of the Act of August, 9, 1963 on the liability for damage caused by atomic ships. This Act was promulgated at the occasion of the visit of an American nuclear submarine to the harbour of Antwerp ${ }^{14}$. The introduction or the absence of strict liability with respect to specific dangerous activities seems also to be influenced by political reasons.

\footnotetext{
12 In the Parliamentary Documents special reference was made to a disastrous fire in La Louvière (Parliamentary Documents of the House of Representatives, 1976-77, Nr. 1054/1, 1).

${ }_{13}$ Parliamentary Documents of the House of Representatives, 1973-74, Nr. 684/4, 2.

14 Parliamentary Documents of the House of Representatives, 1962-63, Nr. 615/1.
} 
In the Parliamentary Proceedings of the Act on nuclear energy, members of Parliament asked the Minister why strict liability was not yet introduced for the licensees of liquefied petroleum gas (L.P.G.) installations or for the petrochemical industry. The Minister answered "that the risks of these activities are indeed at least as high if not higher than the nuclear risk", but continued: "However, these problems are not as sensitive in the public opinion"15.

\subsection{Insolvency solution}

\subsubsection{Duty to insure}

18. As can be learned from the list of strict liability cases in the appendix, the legislator wanted to prevent that an insolvent injurer would not be able to pay the compensation. Two solutions for this insolvency problem are foreseen by statute: a duty to insure and the institution of Compensation Funds.

The duty to insure is defended by referring to the need of adequate victim compensation $^{16}$. The required insurance has only to cover the liability up to the statutory limitation. The duty to insure is enforced by several sanctions ${ }^{17}$.

In the economic literature insurance is seen as an arrangement which might reduce the incentives of the injurer to take care. Given this moral hazard problem, efficiency has to be reached through devices which guarantee an optimal level of care. The insurer could monitor the activity of his insured. This, however, is a costly activity (Shavell, 1984, 361-362). Direct regulation of safety is another means to cure the moral hazard problem.

It can be observed in insurance practice that the insurer is only willing to provide coverage if the applicant meets all the prescribed safety requirements. Employees of the insurance company control the application of these requirements and act in fact as the enforcers of the safety regulation. This is especially true if the controls persist during the whole period of insurance coverage (see further Faure and Van den Bergh, 1986).

19. In several strict liability cases the legislator limited the amount of compensation due by the injurer. The reasons for this limitation are not always clear. In the strict liability case with respect to damage on the ground caused by aeroplanes the legislator argued that the expansion of international air-traffic could be endangered by an unlimited liability. In addition, it was argued that limitation of the liability was a compensation to the injurer for being held strictly liable, which in the eyes of the legislator was a benefit to the victim ${ }^{18}$.

15 Parliamentary Documents of the House of Representatives, 1984-85, Nr. 1207/3, 9.

16 Parliamentary Documents of the House of Representatives, 1976-77, Nr. 1054/1, 2-5 (fire or explosion in public buildings); Parliamentary Documents of the House of Representatives, 1964-65, Nr. $937 / 1,3$ (aeroplanes). The fear that the State Treasure would have to pay the compensation in case of insolvency is advanced in the case of nuclear energy Parliamentary Documents of the House of Representatives, 1984-85, Nr. 1207/3, 5 .

${ }^{17}$ For instance, a building may not be opened to the public without adequate insurance coverage for the strict liability in case of fire or explosion (Art. 8, al. 3, Act of July, 30, 1979). Permission to sail is only given if a vessel has insured its liability for oil pollution (Art. 5, §1, Act of July, 20, 1976). A licensee of a nuclear reactor wil only be officially recognized if he can prove to have insured his liability (Art. 10 Act of July 22, 1985). Every Act provides criminal sanctions.

${ }^{18}$ Parliamentary Documents of the House of Representatives, 964-65, Nr. 937/1, 2. 
Looking for rationales we were struck by the finding that the limitation has always been combined with a duty to insure. In the Parliamentary Proceedings of the Nuclear Energy Act the limitation was clearly linked to the insurability of the risk ${ }^{19}$. In the only case where the law does not provide an explicit duty to insure (liability for damage cuased by atomic ships), insurance coverage was also available.

Given the existence of insurance coverage, the limitation of compensation might be understood as a device which reduces the risks and therefore makes calculating risk and premium less costly for the insurer. Unlimited damages might not be insurable at all. At first glance the limitation does not seem to benefit the victim. However, the disavantage to the victim of not being compensated in the case that his loss exceeds the limitation is partially compensated by the benefit of having a solvent debtor through insurance coverage in those cases.

\subsubsection{Compensation Funds}

20. The goal of the compensation Funds, as formulated by the legislator, is victim protection. For instance in cases of damages caused by toxic waste and mining accidents, The Fund will have to pay the compensation in case of insolvency of the injurer. For damage caused by ground water winning, the Fund also pays advances on the compensation to the victim. This advance payment gives quick compensation to the victim, before a long trial has ended ${ }^{20}$. The amount of these payments is based on equity grounds. If the Fund has made an advance payment, it has a right of redress against the injurer. In that case the risk of insolvency is shifted from the victim to the Fund.

The question should be addressed how the existence of the Compensation Funds affects the incentives of the injurer to take care. In most cases the general tort rules will not basically be changed, since a Fund only pays the compensation if an injurer is insolvent. The possibilities of collusion between the victim and the injurer also seem to be limited. A Fund which paid the compensation to the victim is subrogated in the rights of the victim and has a right of redress against the liable injurer. The Funds usually pay less than full compensation. Hence, the injurer's incentives to take care remain unaffected.

\section{Direct regulation of safety versus tort liability}

\subsection{Economic reasons in favour of safety regulation}

21. In the economic analysis of law several criteria are advanced to justify the implementation of safety regulation: information problems, insolvency, absence of deterrent effect of a tort suit and administrative costs. (Calabresi, 1970, Wittman, 1977, Skogh, 1982, Shavell, 1984). We will examine whether these criteria support the finding of safety regulation in Belgium.

22. Private parties usually have better information on the costs and benefits of a certain activity (Shavell, 1984, 360). In that respect liability rules should be preferred above direct regulation. If the regulator lacks adequate information, an efficient safety device could be imposed. It will of course depend on the concrete type of activity whether the regulatory authorities or the parties in a liability setting have better information. Even though parties

\footnotetext{
${ }^{19}$ Parliamentary Documents of the House of Representatives, 1984-85, Nr. 1207/3, 4-7.

${ }^{20}$ See Parliamentary Documents of the House of Representatives, 1975-76, Nr. 849/1, 2.
} 
generally have an information advantage, in particular cases it may be difficult for them to obtain precise knowledge of the risks involved. Special expertise might be necessary to assess the costs and benefits of a special activity and individuals would probably not have the incentive to make such investment if free riders can benefit from the information. Especially in those cases a regulatory authority might have better incentives, because the costs can be spread.

Some Belgian regulations might be explained by the information advantage of the regulator. One could think of the extensive regulation in the field of environmental law. The companies whose activities are detrimental to the environment might lack the necesary information for an adequate cost-benefit analysis. It might be easier for the Government to assess the risk of a particular activity (Shavell, 1984, 369). The regulation of the transportation of natural gas offers an illustration. The costs for private parties to obtain the necessary information on e.g. the optimal pressure of the natural gas in the pipeline, might be prohibitive.

23. If an injurer is not able to pay for the harm caused, liability rules cannot provide optimal incentives. Since the injurer will consider the damage as a loss equal to his assets, a risk of underdeterrence emerges. Direct regulation of safety could remedy this problem, unless the regulations are enforced through monetary sanctions which again are higher than the assets of the injurer. This would only shift the problem (Shavell, 1984, 360).

In Belgium safety regulation is not expressly promulgated to cure the insolvency problem. The traditional way to overcome this problem is by insurance coverage, which however creates moral hazard problems. This might explain why safety regulation is extensive in areas where the activity is subjected to (compulsory) insurance. The clearest example can be found in the area of traffic accidents. Not only is there a detailed regulation with respect to safety requirements for cars. In addition, many rules, contained in the Traffic Code, govern the conduct of car drivers. These regulations, together with deductables and a monitoring system included in the insurance, can be explained as devices to overcome the moral hazard problem. Although there is no clear connection with the insolvency problem, several Belgian regulations of safety can often be found in areas where the problem exists.

24. If it is difficult to enforce liability through a law suit, the deterrent effect of tort law is reduced. This might be caused by difficulties in proving the fault and the causation. For instance, if the damage becomes apparent only several years after the tortuous conduct, the tort system might not give the appropriate incentives to the injurer. Likewise in cases of long latent diseases difficulties of proof might hinder the deterrent effect. This risk of underdeterrence led some authors to prefer direct regulation of safety in the mentioned cases (see e.g. Boden, 1984, 515).

While it is not always clearly pronounced by the legislator, safety regulations with respect to e.g. toxic waste and water pollution might precisely be explained by this consideration. In the mentioned cases the harm may only become apparent after several years or the victim might even ignore that the harm was caused by a tortuous act, thinking that his disease has a "natural" origin (Shavell, 1984, 363). Finally, the harm may be spread over many victims or the harm may not be individualized at all (e.g. the acid rain problem). In the last hypothesis no one may have sufficient incentives to file suit. These considerations are applicable in the area of environmental law and might explain the extensive safety regulation in this field in Belgium. 
25 . Both liability rules and regulation involve costs. In the case of a liability rule these costs are the costs of private parties (e.g. time, legal fees) and public costs (e.g. salaries of judges, court houses). The costs involved in regulation relate to the costs of establishing and enforcing compliance with mandated standards (Oi, 1984, 439). According to Shavell the tort system is to be preferred to regulation as far as the administrative costs are concerned. In a tort system the costs occur only if an accident actually happens. Costs of regulation are always present, irrespective of the occurence of an accident.

Regulation in Belgium is usually issued without a clear reference to the calculation of administrative costs. Despite the lack of extensive cost information, there can be no doubt that the costs of administering regulation in Belgium are high, especially because the regulations are found in combination with liability rules.

Regulation in Belgium is also imposed in areas where the expected accident costs are high. Oi points at a relationship between the magnitude of the loss and the administrative costs. According to him, a tort system could produce inefficiently large litigation costs if the accident costs are very high (Oi, 1984, 439). Inasmuch as regulation is promulgated with respect to accidents which cause serious damage, Oi's argument supports safety regulation as it exists in Belgium.

\subsection{Liability rules and direct regulation combined}

26. Belgian law does not see safety regulation as a complete alternative for liability rules. In the economic literature arguments in favour of this combination are only advanced in very specific situations. Shavell argues that the lower administrative costs and the information advantage of the parties are arguments in favour of the tort system. On the other hand, the insolvency problem and the risk that a tort suit will not be filed favour the safety regulation. Therefore, in some cases liability rules as well as direct regulation of safety can be used if all the mentioned elements are equally important (Shavell, 1984, 365). However, the arguments in favour of one of two devices will often be preponderant. For example, in environmental law most elements seem to indicate a preference for direct regulation.

27. It is important to examine the influence of safety regulation on the tort system, since these devices are not considered to be alternatives. In Belgium every violation of a regulatory standard will automatically result in a finding of negligence. For instance, if an industry which has to obtain a licence according to the legislation on dangerous, unhealthy and troublesome installations, violates the conditions of the licence, fault is established. That industry will be liable for the harm caused by the violation of the licence, if the blameworthiness requirement is met and no grounds of justification are available. On the other hand, an injurer will not be released from liability just by complying with the regulatory standard. The level of care required by those standards is only a minimum and does not automatically coincide with the general duty of care. For instance, in the given example the industry will not automatically be released from liability if it complies with the safety requirements of the licence.

These rules merit a comment. According to Shavell non compliance with a regulatory standard should not automatically result in a finding of negligence. Following the standard might be innefficient for some injurers. By making every violation a "fault" those injurers are given wrong incentives. They have to comply with the regulatory standard, even if it 
were inefficient for them to do so $^{21}$. It is useful in this respect to refer to the bonus pater familias standard discussed above. Atypical parties might be able to avoid a loss at lower costs, e.g. because they pose lower risks than normal. The regulator cannot identify atypical parties and therefore a single regulatory standard will be used. Hence, it is best for those parties not to comply with the standard. Shavell also indicates that compliance with a safety standard should not automatically release from liability (Shavell, 1980, 365-366). If this were the rule, no one would spend additionally on care, even if this were to reduce the expected accident costs beneficially. Belgian tort law gives injurers this incentive, since compliance with the regulatory standard does not release from liability. Spending additionally on care might be necessary to meet the due care standard.

28. If arguments can be advanced in favour of the combination of safety regulation and liability rules it should be examined which liability rule is best suited on efficiency grounds. In Belgium safety regulation can be found both in combination with a fault rule and with strict liability. The legislator justifies the combination of strict liability and safety regulation by reference to the concern for victim protection. Assuming that even the best measures of prevention would not totally exclude the accident risk, the right to compensation of the victim was, in the eyes of the legislator, best guaranteed through the introduction of strict liability. Moreover, strict liability is often combined with compulsory insurance, which equally aims at victim protection.

The combination of strict liability and safety regulation merits further discussion. One could argue that if the regulator is better informed than the parties in a liability setting, regulation might be appropriate. In most cases of strict liability, laid down in Belgian special statutes, the regulator might have an information advantage (e.g. toxic waste, transportation of natural gas, nuclear accidents). Although this might justify the introduction of safety regulation, it does not explain the combination of strict liability and direct regulation of safety. The insolvency of the injurer is advanced as another argument in favour of safety regulation, especially if the losses exceed the injurer's assets. In the discussion of strict liability we already stressed that a fault rule might provide better incentives in such a situation, because it remedies the risk of underdeterrence. Regulation sis supported by the same argument, but it cannot easily be understood how this argument can lead both to safety regulation and to the introduction of strict liability. Against this analysis one could point at the compulsory insurance, which would remedy the underdeterrence risk. However, the duty to insure is not always present. Further, if compulsory insurance were to solve the problem of underdeterrence, this would no longer be an argument for safety regulation either. Finally, the cumulative effect of strict liability, direct regulation of safety and compulsory insurance might become very costly.

It might be preferable to combine safety regulation and a fault rule. First, the risk of underdeterrence is less serious under a fault rule, because the injurer will take care as long as his costs of care are lower than his assets. Second, under a fault rule regulation has a function. The regulation sets a due care standard and can therefore contribute to the

21 This "inefficiency" is partially compensated by the considerable administrative costs resulting from a detailed individualization. 
avoidance of errors in the determination of the due care standard. The standard could in fact guide parties in their conduct of taking care. Finally, the enforcement problem created through safety regulation, which is also advanced as a reason for the combination of liability rules and regulation (Wheeler, 1984, 600), might be less serious under a fault rule. As mentioned above, most of the liability cases under the Belgian fault rule are a violation of a regulatory norm. Therefore, the victim has incentives to prove that a regulatory standard has been violated. This should give injurers incentives to compliance. This advantage does not seem to be present under a strict liability rule, where the victim only has to prove that he was harmed by the conduct of the injurer, irrespective of any violation of a regulatory norm. In contrast, under a fault rule, the victim often becomes the enforcer of the safety standards. These considerations lead to the conclusion that the Belgian regulator should give more attention to the possibilities of the joined use of safety regulation and the traditional fault rule.

\section{Concluding remarks}

21. An introductory economic analysis of Belgian liability law shows that some legal rules can be explained through the economic model of tort law. Although this model has been developed in a Common Law context, it seems also suitable for analyzing civil law concepts. Basic concepts of the fault liability appear to have an economic rationale. The requirement of blameworthiness guarantee that the duty to compensate will influence the incentives of the injurer to take care. A more severe application of the bonus pater familias standard with respect to professionals seems economically justified as well. The introduction of strict liability in Belgium can, to a certain extent, also be explained on economic grounds. Most of the activities, for which strict liability was introduced in Belgian law, have an ultrahazardous character.

The deviations from the economic model which we find in Belgian liability law, can partially be attributed to the consideration of distributional effects. Belgian legal doctrine stresses the concern for victim protection. In cases where the blameworthiness requirement is not met and the injurer is nevertheless held liable, equity considerations are the underlying rationale. Another deviation from the economic model of tort law, the absence of strict liability for some ultrahazardous activities, can partially be explained by the characteristics of the Belgian legislative pocess. Political considerations seem more important to the Government than economic reasons.

It is striking to notice that in all the cases of strict liability in Belgian special statutes compensation of the victim, in case of insolvency of the injurer, is guaranteed through different devices. It merits further research which of those devices, compulsory insurance or the institution of Compensation Funds, is best suited on efficiency grounds in specific situations. Similarly "overregulation", which is partially promulgated for the sake of victim protection, warrants further research, especially in fields governed by strict liability. In addition, it should be examined whether regulation in combination with a fault rule is the preferable solution, both on efficiency grounds and for the sake of "victim protection". 


\section{REFERENCES}

BOCKEN, H. (1984) "Van fout naar risicio. Een overzicht van de objectieve aansprakelijkheidsregelingen naar Belgisch recht", Tijdschrift voor Privaatrecht, 329-415.

BODEN, L. (1984) “Comment on Epstein”, The Journal of Legal Studies, 13, 507-516.

BROWN, J. (1973) "Toward an economic theory of liability", The Journal of Legal Studies, 2, 323-349.

CALABRESI, G. (1970) The Costs of Accidents, New Haven, Yale University Press.

CALABRESI, G. and HIRSCHOFF, J. (1972) "Toward a test for strict liability in tort", Yale Law Journal, 81, 1054-1085.

CALABRESI, G. (1975) “Optimal deterrence and accidents”, Yale Law Journal, 84, 656-671.

CHELIUS, J. (1976) "Liability for industrial accidents: a comparison of negligence and strict liability systems", The Journal of Legal Studies, 5, 293-309.

DIAMOND, P. (1974) "Single activity accidents", The Journal of Legal Studies, 3, 107-164.

EPSTEIN, R., GREGORY C. and KALVEN, H. (1984) Cases and Materials on Torts, Boston, Little, Brown \& Co.

FAURE, M. and VAN DEN BERGH, R. (1986) "Strict liability and compulsory insurance under Belgian law", Working Paper presented at the 13th Seminar of Risk and Insurance Economists organised by the Geneva Association, Hamburg, September 22-24, 1986.

HADDOCK, D. and CURRAN, C. (1985) "An economic theory of comparative negligence", The Journal of Legal Studies, 14, 49-72.

LANDES W.M. and POSNER R.A. (1981) "The positive economic theory of tort law", Georgia Law Review, 15, 851-924.

LANDES, W.M. and POSNER R.A. (1984) "Tort law as a regulatory regime for catastrophic personal injuries", The Journal of Legal Studies, 13, 417-434.

LIMPENS, J., KRUITHOF, R. and MEINERTZHAGEN-LIMPENS, A. (1982) Liability for one's own act, in International Encyclopedia of Comparative Law, XI, Torts, 2, Tübingen, J.C.B. Mohr Verlag

OI, W.I. (1984) "Tort law as a regulatory regime: a comment on Landes and Posner", The Journal of Legal Studies, 13, 435-440.

PEETERS, B. (1985-86) "Verslag van de werkvergadering «Recht en Economie» te Antwerpen", Rechtskundig Weekblad, 1324-1328.

POLINSKY, A.M. (1984) "Economic analysis of law as a potentially defective product: a buyer's guide to Posner's Economic Analysis of Law", Harvard Law Review, 1974, 87, 1655-1681.

POLINSKY, A.M. (1980) "Strict liability versus negligence in a market setting", American Economic Review, 70, 363-367.

POLINSKY, A.M. (1983) An introduction to Law and Economics, Boston, Little Brown \& Co.

POSNER, R.A. (1972) "A theory of negligence”, The Journal of Legal Studies, 1, 29.

POSNER, R.A. (1977) Economic Analysis of Law, $2^{\text {nd }}$ Ed., Boston, Little Brown \& Co.

POSNER, R.A., Economic Analysis of Law, $3^{\text {rd }}$ Ed., forthcoming (unpublished manuscript).

SHAVELL, S., (1980) "Strict liability versus negligence", The Journal of Legal Studies, 9, 1-25.

SHAVELL, S. (1984) "Liability for harm versus regulation of safety", The Journal of Legal Studies, $13,357-374$. 
SIMOENS, D. (1980-81) "Hoofdlijnen in de evolutie van het aansprakelijheidsrecht", Rechtskundig Weekblad, 1961-1990 and 2025-2036.

SKOGH, G. (1982) "Public insurance and accident prevention", International Review of Law and Economics, 2, 67-80.

VANDENBERGHE, H., VAN QUICKENBORNE, M. en HAMELINCK, P. (1980) "Overzicht van rechtspraak. Aansprakelijkheid uit onrechtmatige daad (1964-1978)", Tijdschrift voor Privaatrecht, 1139-1475.

VAN OEVELEN, A. (1986) "Enige bedenkingen van een jurist bij de economische analyse van het aansprakelijkheidsrecht", in Verslagboek Eerste Werkvergadering Recht en Economie, Antwerpen, Handelshogeschool, 21-30.

VELJANOVSKI, C.G. (1981) "The economic theory of tort liability - toward a corrective justice approach", in The Economic Approach to Law, Burrows, P. and Veljanovski C.G., (Ed) Londen, Butterworths, 125-150.

WHEELER, M. (1984) "The use of criminal statutes to regulate product safety", The Journal of Legal Studies, 13, 593-618.

WITTMAN, D. (1977) "Prior regulation versus post liability: the choice between input and output monitoring", The Journal of Legal Studies, 6, 193-211. 


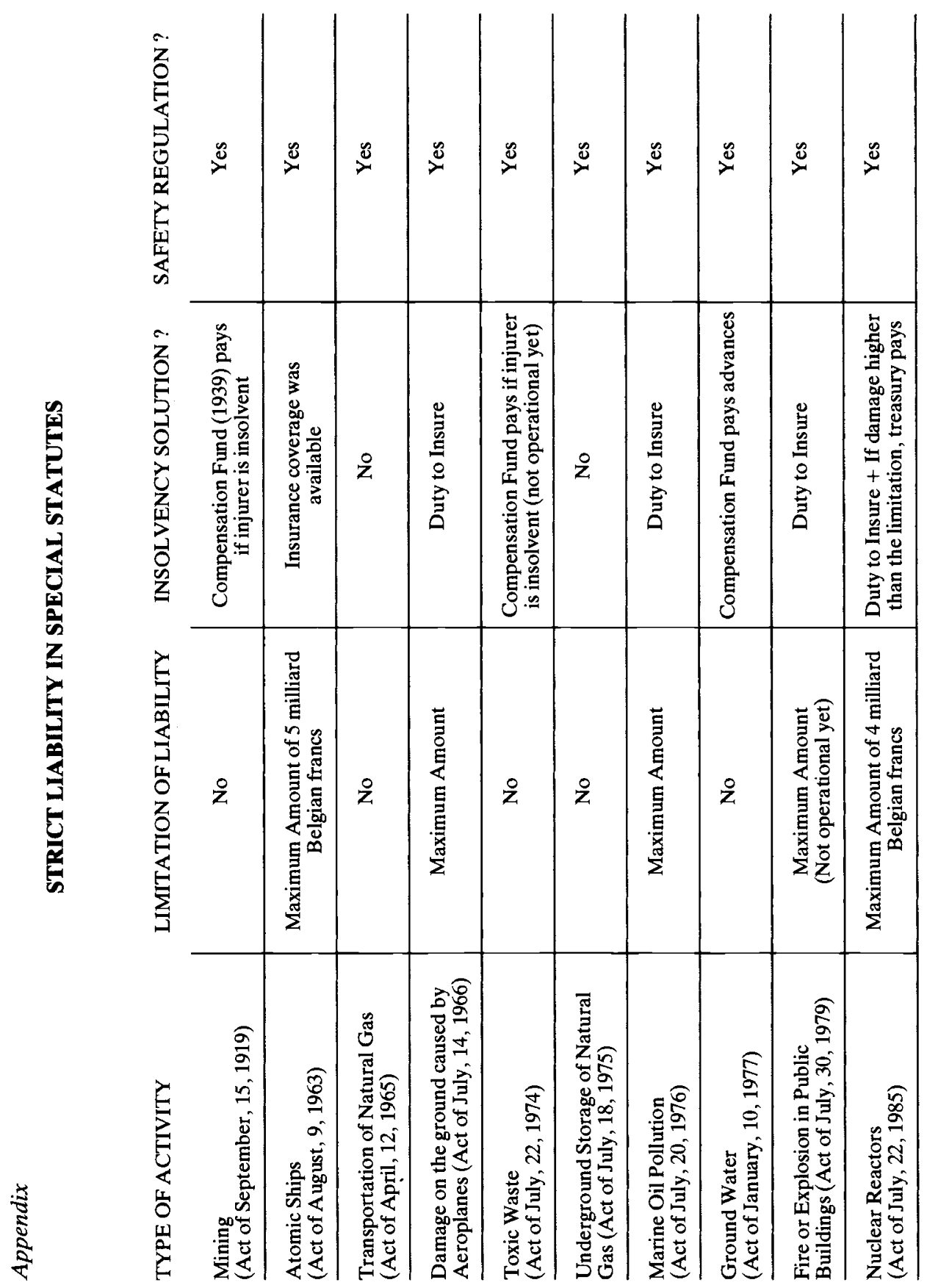

